\title{
ENVIRONMENTAL TAXES IN THE CZECH REPUBLIC
}

\section{Šárka Sobotovičová}

\section{Klíčová slova:}

Ekologické daně, daň ze zemního plynu a některých dalších plynů, daň z pevných paliv, daň z elektřiny, státní rozpočet, daňový př́ijem

\section{Key words:}

Environmental taxes, natural gas tax and some other gases tax, solid fuel tax, electricity tax, state budget, revenue collection.

\begin{abstract}
Abstrakt
Tento článek se zabývá zavedením ekologických daní v České republice v návaznosti na předpisy Evropské unie. Analyzuje postavení těchto daní z pohledu př́ijmů státního rozpočtu.
\end{abstract}

\begin{abstract}
The article deals with implementation of environmental taxes in the Czech Republic depending up the rules of the European Union. It analyses status of the taxes from the state budget revenues perspective.
\end{abstract}

\section{Introduction}

By the year-end 2007 the indirect taxation in the Czech Republic had been formed by value added tax and by the system of excise taxes. ${ }^{1}$ Since 2008 the selective excise taxes have been complemented by a system of the environmental (energy) taxes. These are electricity tax, natural gas tax and other gases tax and solid fuel tax. For Czech Republic, the obligation to implement the proposed system of taxation on solid fuels with effect from $1^{\text {st }}$ January 2008 resulted from European Union law. Law No. 261/2007 Coll. (stabilization of public budgets) regulates this obligation. A separate part of the law is given to each of the above mentioned energy products:

- Part 45 - tax on natural gas and some other gases,

- Part 46- tax on fossil fuels,

- Part 47 - tax on electricity.

\footnotetext{
${ }^{1}$ Excise taxes are in the form of a fixed rate per unit amount levied on fuel, cigarettes and other tobacco products, beer, wine, alcohol and spirits. These are almost the same commodity for which the excise tax is collected in the framework of the EU. Generally, it is a revenue-strong and stable tax. It burdens goods with low elasticity of demand. The main objective in the context of harmonization is to achieve a level of minimum rates, which are binding on states of the European Union. In order to reduce tax evasion, cigarettes, hydrocarbon fuels and lubricants have begun to be signed compulsorily. Taxation on light and very light fuel oil with tax return on oils used for heat has been introduced. A similar mechanism has been introduced also in the case of the so-called green diesel. Incidence of customs duties during the nineties was falling on account of the fact that almost $70 \%$ of import was from EU countries and also in connection with implementation of the so-called association agreements on accession of the Czech Republic to the Union. In 2008 the environmental taxes were introduced in terms of indirect taxation. The aim of environmental taxes is to reduce the existence of negative externalities that affect the environment. Environmental taxes are a specific type of excise taxes, and legislation is in accordance with relevant regulations of the European Community. Environmental taxes in the Czech Republic include a tax on natural gas, solid fuel tax and electricity tax.
} 
Two of three energy taxes were completely new, the tax on solid fuels and electricity. Tax on natural gas was previously included in the tax on mineral oils and had been collected under the mechanism for excise taxes. The customs authorities do the administration of energy taxes, as well as of excise taxes. They also issue permits to purchase of exempted energy products, as well as for purchase of tax-free energy products. Environmental taxes are inherently excise taxes, but they have a different system of taxation, therefore it could not be incorporated into this law. A special legislation was formed instead.

The primary purpose of environmental taxes is to control the existence of privations that affect the environment. These taxes, therefore affect both products and services harmful to health and the environment.

\section{The legislative treatment of environmental taxes}

The basic document for the harmonization of environmental taxes is Council Directive 2003/96/EC restructuring the Community framework for taxation of energy products and electricity. The Directive was issued both to protect the environment, but also because of the unification of legislation of the Community. The fundamental problem in the absence of unified rules on minimum rates of taxation of energy products was the risk of jeopardy of the proper functioning of the internal market. The Directive does not aim to completely regulate the internal market, but leaves member states free to implement their own policies and provides the possibility to apply a various advantages to certain methods of use of the energy products.

Minimum levels of taxation should reflect the competitive position of different energy products and electricity. ${ }^{2}$ Following the method of their use the directive determines various minimum levels of taxation. Outside the scope of Community rules remains the trade with heat, since it takes place within the community in a very limited extent. Usage of the energy products and electricity is taxed differently for companies and non-commercial use.

Table 1: Minimum levels of taxation applicable to heating fuels and electricity

\begin{tabular}{|l|l|l|}
\hline Energy product & Commercial purposes & Non-commercial purposes \\
\hline Liquefied gas (LPG) & 0 & 0 \\
\hline Natural gas EUR/GJ & 0,15 & 0,30 \\
\hline Coal and coke EUR/GJ & 0,15 & 0,30 \\
\hline Electricity EUR/MWh & 0,5 & 1,0 \\
\hline
\end{tabular}

Source: Council Directive 2003/96/EC, Annex 1 Table C

In connection with the adoption of the directive into the laws of each member state a transitional period, which gave states the necessary time to preparation and adaptation to new levels of taxation, in order to prevent negative side effects, was determined. For example, Council Directive 2004/74/EC allows some member states to apply temporary exemptions or reductions in the levels of taxation of energy products and electricity. Transitional period until 1.1.2007 for the protection of price stability in the member states that would have had problems enforcing the new minimum levels of taxation across the board was granted. Czech Republic had negotiated exemptions and tax reductions until 1.1.2008.

\footnotetext{
${ }^{2}$ Council Directive 2003/96/EC, paragraph 14
} 
Three environmental taxes on energy products, which production or consumption has a demonstrable negative impact on the environment, were introduced in the Czech Republic with effect from 1.1. 2008. Only the final energy consumption is subject to taxation and the tax burden falls on the final consumer. If the energy product is supplied for example between merchants, the obligation to declare and pay duty does not arise. Laws are designed to correspond to the requirements laid down in European Union legislation.

The introduction of environmental taxes was expected to achieve certain results not only in terms of revenue to the state budget, but also a positive environmental impact, which should be the primary essence of the inclusion of these taxes to the legal order of the Czech Republic. The introduction of environmental taxes also increases the yield of value added tax, as the value of these taxes enter into the tax base.

The European Commission is preparing a revision of Council Directive 2003/96/EC, which should be effective from 2013. The reason for the change is insufficient emissions taxation, particulary those from the fuel combustion and heating, and the lack of interconnection between the energy taxation system and the EU system of emission permits trading. Another reason is that the taxation of energy meets the diverse range of goals (e.g. increasing the fiscal revenues of the state, reduction of the energy intensity of production) from the goal of reducing greenhouse gas emissions. ${ }^{3}$

The proposed new method of taxation should be a two-component, it means that both consumed energy and $\mathrm{CO}_{2}$ emissions should be taxed. This will bring a change of methodology of determining the tax rates and a change in the minimum rates. The new concept provides for certain energy sources (e.g. coal, natural gas), a significant increase in taxation. Taxation of other energy products (e.g. petrol, LPG) should remain in the same amount.

\section{Particular environmental taxes in the Czech Republic}

\section{Tax on natural gas and other gases}

The law on excise income regulated taxation of natural gas and other gases in the same way as other selected products. Due to the completion of the transitional period, which covered the gas tax, the gas tax system had to be adjusted to suit the requirements of EU legislation, so these products were exempted from the excise tax law and regulated by separate law.

Subject to tax are natural gas, biogas, coal gas, water gas, gas, methane and other gases that are used for engine propulsion, heat production and other purposes specified in the law.

Tax rates are specific to the way of using the gas:

- The heat production $30.60 \mathrm{CZK} /$ Megawatt-hour

- For other purposes set out in the law 30.60 CZK/Megawatt-hour

- For engine propulsion..................................until the end of December 2011, the rate is $0 \mathrm{CZK} /$ Megawatt-hour, this rate will be gradually increased up to $264.80 \mathrm{CZK} /$ Megawatt-hour (since 1.1.2020).

\footnotetext{
${ }^{3}$ My translation TREZZIOVÁ D., Aktuální informace k návrhu revize Směrnice o zdanění energií. http://www.spcr.cz/index.php?view=article \&catid=40\%3Aevropska-komise\&id=2794\%3Aaktualni-informacek-navrhu-revize-smernice-o-zdaneni-energii200396es\&tmpl=component $\&$ print=1\&layout=default\&page $=\&$ option=com_content $\&$ Itemid=72
} 
Exemption for gas used for heat production is determined so as not to increase prices for home heating. Other reasons for exemption are to avoid double gas taxation such as in its use to generate electricity or a comparable tax treatment for fuel.

For the contractor is considered an entity trading with untaxed gas or other supplies. The end consumer is an entity that is authorized to acquire only the gas tax or exempt. Taxpayer is then the contractor who supplied gas to the final consumer or a person who used untaxed or exempted gas for purposes other than intended purpose. Operators of transmission and distribution system and underground gas storage are taxable persons because of the specific nature of carried out activities. The supplier, which supplies the gas entirely to other suppliers and has not an obligation to declare and pay tax, has the status of the payer with no obligation to register for tax purposes.

\section{Tax on fossil fuels}

Solid fuels were not subjects to specific taxation in the Czech Republic by the end of 2007 . Following the European Union rules and the end of the transitional period was to introduce as from 1.1. 2008 the minimum rates of excise duties on fossil fuels valid in EU.

Subject to tax are the black and brown coal briquettes, coke and semi-coke of coal, lignite or from peat and other fuels. Subjects to tax are also other hydrocarbons listed below the nomenclature codes in the case that they are used for heat. The tax rate is fixed at $8.50 \mathrm{CZK} /$ GJ of combustion heat in the original sample. Exemption is again determined to avoid increasing the price of heat for households and the avoidance of double taxation by environmental taxes. The exemption also applies to fuels that are used for other purposes than for engine propulsion and heat.

Supplier is an entity that trades with untaxed solid fuel or supplies it to others. The ultimate consumer is an entity that does not have a permitting to purchase fossil fuels without taxes. Tax payer, is every entity that supplied the solid fuel to the final consumer, or the one who used untaxed or exempted solid fuel for other than its intended purpose. In the case of consumption of untaxed fossil fuels, the taxpayer may become both the supplier and final consumer. If the supplier who supplies the fossil fuels is not an entity of the Czech tax law, then the final consumer of the fossil fuels established in the fiscal territory becomes a taxpayer.

\section{Electricity tax}

Taxation of electricity was not adapted in the Czech law system before the end of 2007. This obligation is laid down by EU Directives. Electricity is a subject to taxation up to delivery to final consumer. The tax rate is fixed and is set at CZK 28.30. Apart from the general system of taxation, specific tax benefits based primarily on environmental and economic interests apply to the electricity. These include exemption of electricity produced from some renewable resources or consumed immediately for transporting people or goods by mass transport.

The entity that trades with untaxed electricity or supplies it to others (the trader of electricity, electricity producer and electricity market operator) is the supplier. The final consumer is not entitled to acquire electricity without tax, i.e. the electricity which duty to declare and pay has not set in yet. The supplier who supplied electricity to the final consumer becomes the taxpayer. In most cases it is the trader. The distribution and transmission system operators are the taxpayers because of the specific nature of carried out activities as providing transportation of electricity. Taxpayer is also the subject, who was obliged to declare and pay 
tax on specific consumption of electricity or a person who consumed untaxed or exempted electricity for purpose other than the purpose for which the electricity was exempted. If the supplier is not an entity of the Czech tax law, then the final consumer of electricity, established in the fiscal territory, becomes a taxpayer.

The current system of environmental taxes in the Czech Republic is not final. Tax reform has three stages. The first part, started in 2008. The second part, which is supposed to proceed from 2010 till 2013, should include a further increase in rates and introduction of other energy taxes. For example, a CO2 tax for large companies. The final form as well as amount of these taxes depend on political decisions and will be comprehended within the complex of tax changes in connection with the next phase of the reform of public finances. In connection with the environmental penalty, the introduction of a sophisticated system of tax benefits for upgrading facilities that are environment friendly is also prepared. The third (and so far final) phase from 2014-2017 has not yet been conceptually clarified and should be based on the experience of previous years.

\section{The proceeds of environmental taxes}

The proceeds of environmental taxes are fully state budget revenue. During the introduction, the environmental taxes have been presented as revenue-neutral, since the yield should be offset by the reduction in taxes on labour, especially by reducing social insurance. A shift of taxation from factor of labour to taxation of consumption through taxation of products and services with a negative impact on the environment and human health should have become by it. Such compensation would however mean that some groups of inhabitants will not be advantaged and only the new taxes will affect them. This would cause a significant impact on the underprivileged people who do not have the opportunity to invest funds in the purchase of new furnaces. On that account the introduction of special social benefits that will help reduce the tax burden to these groups of inhabitants are also considered.

Considering the limited number of taxpayers and simple system for collecting taxes on electricity, gas and solid fuels, the management of these new taxes is relatively simple and avoids the high costs.

In 2008, the total collection in the amount of approximately CZK 4.3 milliard was expected by the introduction of environmental taxes. Taxation of fossil fuels should represent a tax collection in the amount of CZK 1.7 milliard, the gas tax CZK 1.5 milliards and electricity tax CZK 1.1 milliard.

Table 2: Revenue from environmental taxes in millions of CZK

\begin{tabular}{|l|c|c|c|}
\hline & $\begin{array}{c}\text { Plan } \\
\mathbf{2 0 0 8}\end{array}$ & $\begin{array}{c}\text { Reality } \\
\mathbf{2 0 0 8}\end{array}$ & $\begin{array}{c}\text { Reality } \\
\mathbf{2 0 0 9}\end{array}$ \\
\hline ET in total & 4300 & 2454 & 3180 \\
\hline $\begin{array}{l}\text { ET on natural gas and } \\
\text { some other gases }\end{array}$ & 1500 & 1003 & 1285 \\
\hline ET on fossil fuels & 1700 & 432 & 508 \\
\hline ET on electricity & 1100 & 1019 & 1387 \\
\hline
\end{tabular}

Source: Own processing according to data on www.mfcr.cz/cps/rde/xbcr/SZU2009 
Actual revenue from the environmental taxes in 2008 was finally about CZK 1846 million lower. This nearly $43 \%$ difference was grounded by the fact that it was a prediction with no previous experience with these taxes. In setting the plan it was necessary to rely mainly on statistical data on the consumption of newly taxable products that may show some departure from reality. The largest drop in the amount of CZK 1268 million in tax revenue from solid fuels was influenced by the consumption of fossil fuels purchased in 2007, before the introduction of this tax. The tax on electricity had mostly approached the planned proceeds. Its yield was only about CZK 81 million lower. In 2009, the revenue from environmental taxes increased by CZK 726 million. One reason for this increase was that in 2008 the tax collection for January was zero, since the tax is payable until the $25^{\text {th }}$ of the following month. The biggest increase - CZK 368 million was in tax on electricity. For other taxes, the collection in 2009 did not reach the originally planed revenue for year 2008, as shown in the following graph.

\section{Graph 1: Revenue from environmental taxes}

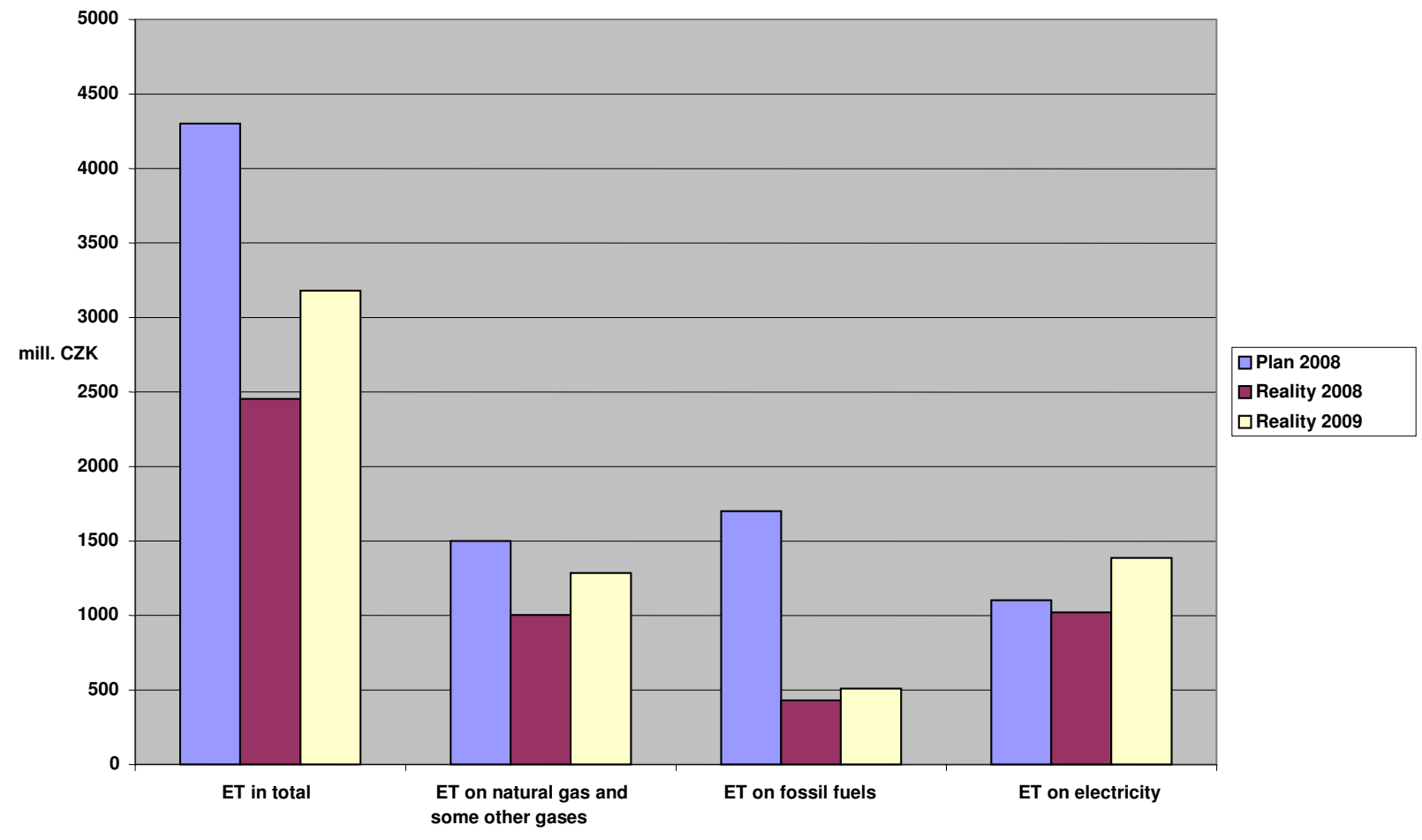

Source: Own processing according to data on www.mfcr.cz/cps/rde/xbcr/SZU2009

\section{Status of the environmental taxes within then tax revenue}

State budget revenues consist mainly of taxes, insurance on social security, state employment policy contribution and non-tax revenues, including the capital incomes. 


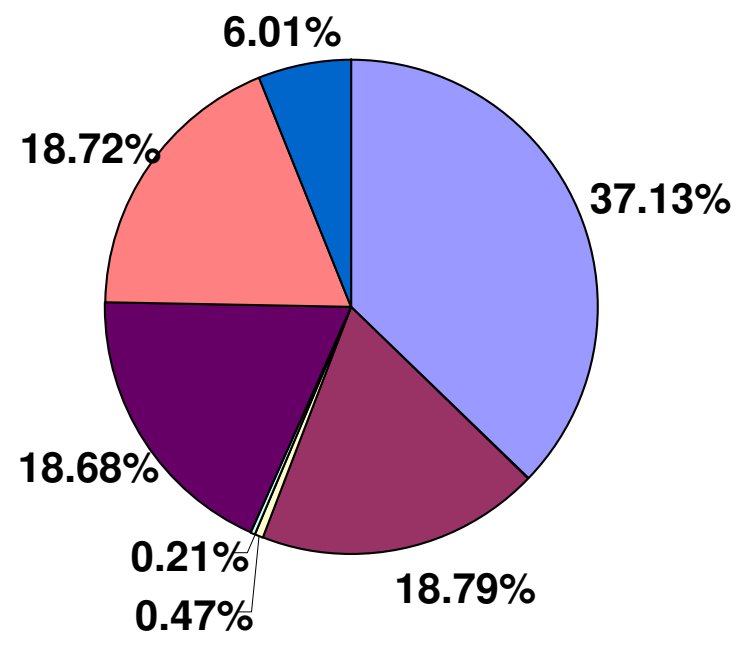

\section{$\square$ VAT $\square$ Environmental taxes \\ $\square \mathrm{CIT}$ $\square$ Excise taxes \\ $\square$ Duty \\ $\square$ Personal income tax \\ $\square$ Property taxes and other taxes and other charges}

Source: Own processing of data according to www.mfcr.cz/cps/rde/xbcr/SZU2009

As it is clear from the above graph, the environmental taxes participate in the revenue of the state budget only $0.47 \%$ in 2009 . In comparison with other excise taxes, the proceeds of all three environmental taxes is CZK 259 million lower than the revenue from beer excise tax, i.e. the excise tax with second lowest yield. On the other hand, the yield on each of the three environmental taxes is higher than the yield on wine and intermediate products. Proceeds of excise and environmental taxes are listed in the table below.

Table 3: Proceeds of excise and environmental taxes in 2008 and 2009

\begin{tabular}{|l|l|l|}
\hline & $\mathbf{2 0 0 8}$ & $\mathbf{2 0 0 9}$ \\
\hline Excise taxes in total & $\mathbf{1 3 0 5 7 2}$ & $\mathbf{1 2 7 8 8 7}$ \\
\hline Tax on mineral oils & 82083 & 79453 \\
\hline Tax on tobacco \& tob. products & 37507 & 37704 \\
\hline Tax on wine and intermediate & 336 & 326 \\
\hline Tax on bear & 3564 & 3439 \\
\hline Tax on wine and intermediate & 7082 & 6965 \\
\hline Environmental taxes in total & $\mathbf{2 4 5 4}$ & $\mathbf{3 1 8 0}$ \\
\hline $\begin{array}{l}\text { Tax on natural gas and some } \\
\text { other gases }\end{array}$ & 1003 & 1285 \\
\hline Tax on fossil fuels & 432 & 508 \\
\hline Tax on electricity & 1019 & 1387 \\
\hline So Own
\end{tabular}

Source: Own processing of data according to www.mfcr.cz/cps/rde/xchg/mfcr/xsl/dane_cla_55467 


\section{Conclusion}

The introduction of environmental taxes was not with the view to increase revenue to the state budget, since these taxes should be revenue-neutral. The reason for their introduction was especially anticipated positive impact on environment. Collection of environmental taxes was lower than the primary presumptions and in addition the economy was affected by recession and therefore the reduction of social insurance was postponed. Economists criticise the plan on to use the social insurance to compensate the environmental taxes, because there is not a compensation for all groups of population, as pensioners for example do not pay the social insurance. What is also facing the criticism is the taxation of electricity regardless of the source, when outdated coal-fired power pays the same taxes as modern one, which thanks to new technologies emits only a fraction of emissions. However, this does not meet the primary aim, which was within the introduction of environmental taxes planned, namely induce businesses to modernize their facilities so as to reduce the environmental burden.

I propose to change the taxation of the environmental taxes to reflect the energy content and the impact on the environment. At current tax rates the most polluting sources are burdened with lower tax rate. It is necessary to introduce taxation of energy products based on content of $\mathrm{CO}_{2}$. The real environmental tax yield is lower than the assumption, and thus the percentage of administrative costs of their collection has increased. In this context it would be appropriate to adjust tax rates in order to maximize income from these taxes to the state budget.

Also in other European Union countries, the situation is the same. Even after introduction of the environmental taxes the current emissions exhaustion is under-taxed and energy taxation system meets the objectives rather different from the original planed intention to reduce greenhouse gas emissions. It is therefore prepared the revision of Council Directive 2003/96/EC that the member states will have to reflect in their legislative directives.

\section{Literature:}

[1] ŠIROKÝ, J. A KOL. Daňové teorie s praktickou aplikací. Praha, C.H. Beck, 2008. ISBN 978-80-7400-005-8

[2] Council Directive 2003/96/ES

[3] Zákon č. 261/2007 Sb., část čtyřicátá pátá daň ze zemního plynu a některých dalších plynů, ve znění platných předpisů

[4] Zákon č. 261/2007 Sb., část čtyřicátá šestá daň z pevných paliv, ve znění platných předpisů

[5] Zákon č. 261/2007 Sb., část čtyřicátá sedmá daň z elektřiny, ve znění platných předpisů

[6] www.mfcr.cz/cps/rde/xchg/mfcr/xsl/statni_zav_ucet_56706 Státní závěrečný účet za rok 2009

[7] www.mfcr.cz/cps/rde/xchg/mfcr/xsl/dane_cla_55467 Informace o činnosti daňové a celní správy České republiky za rok 2009

[8] TREZZIOVÁ D., Aktuální informace k návrhu revize Směrnice o zdanění energií. http://www.spcr.cz/index.php?view=article\&catid=40\%3Aevropska-

komise\&id=2794\%3Aaktualni-informace-k-navrhu-revize-smernice-o-zdaneni-energii200396es\&tmpl=component\&print=1\&layout=default\&page=\&option=com_content\&It emid $=72$ 


\section{Classification JEL: M4}

\section{Ing. Šárka Sobotovičová}

Slezská univerzita v Opavě

Obchodně podnikatelská fakulta v Karviné

Univerzitní nám. 1934/3

73340 Karviná

sobotovicova@opf.slu.cz 